\title{
EMP's first steps in the field of clinical trials
}

\author{
Greetje Goossens \\ From 5th European Conference on Rare Diseases (ECRD 2010) \\ Krakow, Poland. 13-15 May 2010
}

The development process of clinical trials has for long been the territory of the researchers, healthcare providers and regulators. Patients were only involved as "subjects" and had a passive role. However, in the last decennium, patients and their advocates have been moving more towards an active participation in the development of clinical trials. Many stakeholders realise that by actively involving patients, a patient tailored system of care can be achieved. However, it can be quite a challenge for patient organisations, who often work with volunteers and limited manpower to act as an equal partner in this specialised area where deadlines, standards and certain work principles have to be met. Moreover, patient representatives need to acquire enough "literacy" in this highly scientific environment. This document presents the case of a young patient organisation EMP and the way EMP handled this challenge. It explains how a patient organisation can proceed step by step to meet the exigent criteria and how literacy can be gained through different training programmes. The document further explains how EMP started active involvement in the development of clinical trials, by initially only focusing on activities that were within realistic reach of the group. These first prudent steps gave the patient representatives further knowledge and research skills; it gave them confidence and it created a relationship of trust with the other stakeholders. These are probably strong foundations for more extensive collaboration in the field of clinical trials in the future.

Published: 19 October 2010

doi:10.1186/1750-1172-5-S1-O24

Cite this article as: Goossens: EMP's first steps in the field of clinical trials. Orphanet Journal of Rare Diseases 2010 5(Suppl 1):O24.

Correspondence: g.goossens@emp-myeloma.eu

European Myeloma Platform, Chemin du Lanternier 26, Lasne 1380, Belgium

Submit your next manuscript to BioMed Central and take full advantage of:

- Convenient online submission

- Thorough peer review

- No space constraints or color figure charges

- Immediate publication on acceptance

- Inclusion in PubMed, CAS, Scopus and Google Scholar

- Research which is freely available for redistribution

Submit your manuscript at www.biomedcentral.com/submit
C Biomed Central 